\title{
Implementing Wind Power Policy - Institutional Frameworks and The Beliefs of Sovereigns
}

\author{
David Newell ${ }^{1}$ \\ Luleå University of Technology \\ Division of Social Science \\ 97187 Luleå \\ Sweden \\ E-mail to corresponding author: david.newell@1tu.se
}

\begin{abstract}
As the development of renewable energy remains prominent on the global policy agenda, international organizations and states have created policies intended to foster renewable energy development. With wind power projected to make the largest contribution to Europe's renewable energy mix, the EU and EU member-states have attempted to create institutional frameworks favoring the development of wind power. In many cases, however, this has proven to be a necessary, but insufficient, condition for wind power development, making wind power policy an interesting case of policy implementation. Because of the inherently local nature of wind power development, the influence of local actors and institutions on the policy process must also be considered. This article suggests how a proposed theoretical development in the Advocacy Coalition Framework can be used to explain how concerns exogenous to local policy subsystems can affect local political decision-making and policy implementation. This approach is then used to examine the case of wind power development in Markbygden, Sweden and finds partial support for the effect of exogenous concerns on local political decision-making.
\end{abstract}

Keywords: policy implementation; energy policy; renewable energy; wind power; advocacy coalition framework.

\footnotetext{
${ }^{1}$ Present address: 1067 Waterford Drive, Provo, UT, 84604, USA
} 


\section{Introduction}

\subsection{Background}

A major contribution of the scholarly study of policy implementation has been to elucidate the myriad obstacles that stand between political decisions-policy intentionsand the results of those decisions-policy outcomes (c.f. Wildavsky 2007). For example, rather than asking why do policies fail? Pressman and Wildavsky (1973) assert why it's amazing that [policies] work at all. Given this, policies that do work as envisioned become interesting objects for study. In the study of policy implementation, asking what went right? is just as - if not more - interesting than the question of what went wrong?

In an effort to address climate change, the EU created the EU 2020 targets, specifying that at least $20 \%$ of EU power consumption should come from renewable energy resources by 2020 (European Union 2014). These goals were recently updated in the EU 2030 framework, which stipulates that $27 \%$ of energy consumption should come from renewables by 2030 (European Commission 2014). In order to reach these EU-wide targets, EU states have set state-level targets, which vary based on countries' energy consumption, production capabilities and existing energy mix. However, these efforts have met with varying levels of success, with some countries surpassing their targets, but some failing to meet them so far (European Union 2013).

Wind power is projected to contribute the most to meeting EU member-countries' renewable energy production goals. Therefore, determining how to successfully encourage the development of wind power in EU countries is critical to implementing the EUs renewable energy policy. However, despite binding targets at the international level, as well as legal frameworks and financial incentives at the national level, wind power development has proceeded with varying levels of success (Nadai 2007, Söderholm et al. 2007, Szarka 2007, Nadai 2009, Clement 2010, Ek et al. 2013) despite enjoying general, popular support (Jobert et al. 2007, Nadai 2007, Todt 2011). The EU thus presents a classic case of where policy intentions - of both political elites and the general publicfail to align with policy outcomes. However, while wind power development has not proceeded as envisioned in some cases, in other cases it has. Cases of successful wind power implementation in the EU are therefore of special interest for illuminating what went right in policy implementation.

This article suggests how a proposed theoretical development of the Advocacy Coalition Framework (ACF) can be used to study wind power (as well as other) cases of policy implementation. After reviewing the literature on policy implementation generally, wind power policy implementation, and policy subsystems, the outlines of a framework for policy subsystem interactions will be drawn. This framework is then used to understand a case of successful wind power development in Piteå, Sweden. This will be followed by a discussion of how this study contributes to a better understanding of both policy implementation and the ACF itself.

\subsection{Previous Research}


Since the publication of Implementation (Pressman and Wildavsky 1973), policy implementation has been a major focus of academic policy research. Pressman and Wildavsky's work served as a catalyst for this research by emphasizing "why it's amazing that federal programs work at all." Since then, policy implementation research has grown, encompassing a broad range of policy areas (cf. Smith 1973, Montjoy and O’Toole 1979, Matland 1995, O'Toole 2000). And, despite changes in emphasis and nomenclature, policy implementation research has continued as an area of scholarly interest in more recent times (Saetren 2005).

Wind power policy implementation research has taken divergent paths, focusing on either the local level of implementation or the national/regional level. At the local level, most of the research on wind power policy implementation has been from the perspectives of social acceptance and the planning process. Researchers using the former approach have identified public participation, values and beliefs, local profitsharing/ownership, local geography and economy, and aesthetic and landscape considerations and local support networks as important determinants of local acceptance of wind power development (Todt et al. 2001, Khan 2003, Devine-Wright 2005, Jobert et al. 2007, McLaren-Loring 2007, Breukers and Wolsink 2007, Agterbosch and Breukers 2008). Most research has also concluded that local opposition to wind power development cannot simply be ascribed to the NIMBY (Not-In-My-BackYard) effect (Warren et al. 2005, Devine-Wright 2005, Jobert 2007, Breukers and Wolsink 2007), i.e. the phenomenon of people wanting a particular development, but only as long as it is not located near them. Researchers using the planning process approach have focused on how planning instruments and siting procedures favor or hinder wind power development (Nadai 2007, 2009), public participation and stable networks in the planning process (McLaren-Loring 2007), local ownership (Toke et al. 2008), and municipal planning capacities and the strength of policy measures (Khan 2003). These studies have revealed how the local dynamics of wind power development influence policy implementation. Yet, these approaches do not account for the influence of actors and institutions of the national level in a theoretically systematic way, nor do they explain how the national and local levels interact.

Research on wind power policy implementation at the national/regional levels, on the other hand, has primarily taken historical institutionalist or policy subsystem approaches. Historical institutionalist approaches (c.f. Breukers and Wolsink 2007, Toke et al. 2008, Agterbosch and Breukers 2008, Ferguson-Martin and Hill 2011) have illuminated how national level institutions that affect local level policymaking are the result of decisions made at critical junctures, as well as subsequent path dependencies. Policy subsystem approaches (Szarka 2004, 2006, 2010, Wiener and Koontz 2010, Jegen and Audet 2011) have shed light on the process by which wind power policy has developed as the result of coalition behavior, or the actions of groups of actors bound together by similar beliefs. In such analyses, the local level is considered to a degree, but only as a part of larger national or regional policy subsystems. However, national-level actors and institutions deal with wind power development in terms of developing various energy resources, e.g. wind, solar, hydro, nuclear, coal or gas power, or, in other words, in terms of national energy policy. Local actors and institutions, on the other hand, tend to 
view local wind power development in terms of the effects it will have on land use. From a land-use perspective, energy development is usually not a question of developing wind or solar or nuclear power. Rather, it is a question of the impact of developing energy resources on existing and potential land uses, such as housing, farming, forestry, recreation and natural beauty.

Because the substance of energy policy differs from the substance of land use policy, the interests and concerns of actors involved in the policy processes dealing with wind power at the national or local levels may not always align. While there are differences between countries, institutional frameworks that grant local authorities substantial discretion in the permitting process for wind power development are the most common (IEA 2007). In places where land-use decisions are made at least in part locally, understanding wind power policy implementation requires understanding both the energy policy process and the land use policy process. Economic, financial, legal and other measures--i.e. the policies or institutional frameworks--created at the national level, while certainly influencing the prospects for wind power development, only provide the framework within which local actors determine where, if, and to what extent wind power is actually developed in relation to other land-use possibilities. This dynamic explains why "wind power projects are increasingly confronted by local opposition which delays or blocks implementation despite the fact that the level of general public support for wind energy is high and stable" (Breukers and Wolsink 2007) and why national institutional frameworks designed to encourage wind power development through incentives, etc. have proven insufficient in many cases to promote significant wind power development (Söderholm et al. 2007, Szarka 2007, Nadai 2007, 2009, Clement 2010).

\subsection{Aim}

The aim of this article is to understand why local authorities decide to permit wind power development in situations where 1) national authorities have created institutional frameworks encouraging the development of wind power, yet 2) local authorities have significant discretion concerning wind power development. To achieve this aim, a theoretical model will first be developed, based on the ACF, that explains the interaction of the energy policy subsystem and land use policy subsystems in terms of institutional frameworks, the beliefs of sovereigns, policy outputs and policy outcomes. Based on this model, hypotheses concerning what influences local sovereigns, and their beliefs, will be derived and then tested using a case of successful wind power development. Doing this will elucidate the mechanisms by which the national and local levels, or the energy and land use subsystems can potentially interact, and thus provide an explanation for why wind power policy implementation may have been successful in the specific case being studied in this article.

\section{Theory}

\subsection{Policy Subsystems and the Advocacy Coalition Framework}


Policy implementation across different levels of government has been understood in terms of cross-scale linkages (Young 2002, Berkes 2002), multi-level governance (Hooghe and Marks 2003), polycentrism (Ostrom 2001, Imperial 2005, Skelcher 2005) and nested enterprises (Ostrom 1990, Lundqvist 2004). This article hypothesizes, as will be expounded upon later, that one of the causal mechanisms explaining policy implementation across different level of government is beliefs. Therefore, the Advocacy Coalition Framework will be used because of its emphasis on the centrality of beliefs in the policy process. The ACF offers a comprehensive explanation of the policymaking process and its actors and has proven to be a useful tool for examining policy stability and policy change in a number of areas, most prominently in policy subsystems dealing with natural resource management (Sabatier and Brasher 1993, Sabatier and JenkinsSmith 2007, Sotirov and Memmler 2012).

The ACF integrates several developments in actor- and subsystem-based frameworks of the policy process into a theoretically coherent, empirically testable model. ACF parameters include examining policy processes over a period of ten years or more to capture real policy change (Sabatier and Jenkins-Smith 1993:16), a focus on policy subsystems (substantive, territorially defined, policy-domains (Sabatier and Jenkins-Smith 2007)) incorporating actors from across governmental entities as well as private and civil-society actors, and conceiving of public policies as belief systems (Sabatier and Jenkins-Smith 1993:16). Within subsystems, different advocacy coalitions, comprising actors who share normative and empirical beliefs about a given policy area (Ibid:18), compete to shape public policy. In the ACF, actors are goal-oriented, but the preferences of advocacy coalitions play a more important role than in utilitarian models (Sabatier and Jenkins-Smith 2007:30), i.e. actors are "boundedly rational."

Advocacy coalitions, beliefs and subsystem policy processes can shift and change as the beliefs of actors shift and change through processes of policy learning. Policy learning through communication and feedback from policy outputs can affect the secondary beliefs (nonessential, technical beliefs about the policy issue) of actors and cause them to shift or collaborate in new ways, thereby affecting policy outputs (Sabatier and Jenkins-Smith 1993:19). In order to change policy core beliefs, however, larger changes, exogenous to the subsystem, are usually necessary. Such events can include socioeconomic changes, changes in a government ruling coalition, changes in the resources attached to or attributes of the policy area itself, negotiated agreements between opposing coalitions, or policy decisions and impacts from other policy subsystems (Sabatier and Jenkins-Smith 1993:20, Sabatier and Jenkins-Smith 2007). In the absence of one or more of these conditions, policy can be expected to remain relatively stable over time (Sabatier and Jenkins-Smith 2007).

\subsection{Policy Processes Spanning Multiple Subsystems}

From the ACF perspective, and in contexts where institutional frameworks grant significant local autonomy over land use decisions, energy and land use policies can be understood as belonging to two separate policy subsystems. While a given policy subsystem may contain both local- and national-level actors, the subsystems themselves 
are substantively (i.e. in terms of what policy issue they deal with) and territorially delimited. Defining these policy arenas as separate subsystems is useful in the case of wind power policy implementation because it delineates the two subsystems (energy and land use) in terms of the different interests, trade-offs and beliefs of actors that exist in the two separate policy arenas. Defining clear subsystem boundaries delimits what decisions and policy outcomes and impacts are endogenous or exogenous to a given subsystem and provides the basis for understanding how subsystems can affect each other.

In terms of the energy policy and land use policy subsystems, there are three primary distinctions. First, the territory of the subsystems differ. The energy policy subsystem comprises the entire energy system of a country and is national in scope, whereas land use policy subsystems are limited in scope to the geographic jurisdictions of local authorities. Second, the policy contexts of the two subsystems differ, with energy subsystems dealing with wind power development in relation to other means of producing energy, such as solar, nuclear, hydro, etc., and land use subsystems dealing with wind power in terms of its impact on existing or potential land uses. Finally, and as a result of the above-mentioned distinctions, the relevant institutions and actors with authority for administering energy subsystems and land use subsystems differ significantly. The energy subsystem comprises national legislative, executive and judicial branches of government with actors ranging from national politicians, bureaucrats and judges, corporations and unions, as well as global and national activists and other civil society groups. On the other hand, land use subsystems include city councils, courts and municipal organizations and mostly local interests groups, citizens, politicians, bureaucrats, judges, companies, activists, etc. For these reasons, understanding the wind power policy process as belonging to two distinct policy subsystems helps to explain why policy intentions in the energy subsystem are, or are not, realized in the policy outcomes of land use policy subsystems. When the interests and beliefs of actors within each policy subsystem differ significantly, policy outputs can be expected to differ and, hence, policy outcomes may not align with the policy intentions of the energy policy subsystem. Yet, simply understanding that the wind power policy process belongs to two policy subsystems is insufficient to understanding wind power policy implementation. It is therefore necessary to also determine the mechanisms by which the energy policy subsystem affects land use policy subsystems.

\subsection{Policy Subsystem Interactions and Sovereigns}

An understanding that policy subsystems affect each other is not new, but it is only more recently that the dynamics of policy subsystem interactions have begun to be elucidated (Jochim and May 2010). There is due to a recognition that a growing number of policy areas, such as environmental policy, "span traditional subsystem boundaries, requiring a serious look at subsystem structures and interdependence" (Weible et. al 2009). Yet, trans-subsystem change "has been underspecified" (Jones and Jenkins-Smith 2009) and the existing theory is limited (Jochim and May 2010). While some work has recently been done explaining the factors that affect subsystems, including "policy 
regimes," "spillovers" and "policy disruptions" (May et. al. 2009, Jochim and May 2010,), as well as public opinion, policy issue venues and "clusters of linked subsystems" (Jones and Jenkins-Smith 2009), most of these factors are variables exogenous to policy subsystems. Thus, what has been addressed in the research so far has been more what factors external to subsystems affect them, rather than how those factors affect subsystems. What is lacking, from a theoretical perspective, is an explanation for what elements endogenous to a given policy subsystem could affect elements endogenous to other policy subsystems, i.e. the mechanisms of policy subsystem interaction.

According to the ACF, policy change can occur when policy learning occurs within a given policy subsystem (Sabatier and Jenkins-Smith 1993:18). Policy learning can be induced by events--such as policy decisions and impacts--in one subsystem that have ramifications in other subsystems, thus forcing actors in the other subsystems to identify and respond to challenges to their belief systems (Ibid:43). This explains why decisions and policy impacts from a subsystem, such as the energy subsystem, can induce policy change in other subsystems, such as land use subsystems.

The policy impacts from energy policy subsystems that affect land use policy subsystems occur when decisions by sovereigns in energy subsystems are made that change the constraints and resources of subsystem actors (what I will refer to as the institutional framework) of land use subsystems. According to the ACF, the constraints and resources of subsystem actors affect the beliefs (and hence the decisions) of the actors in a subsystem (Sabatier and Jenkins-Smith 1993:18). That is, changes to constraints and resources by the energy subsystem affect the rules of the game within which land use subsystems operate by changing, for example, planning and permitting rules or economic and financial rules, such as tax- and renewable-certificate incentives. However, whether policy outcomes in land use subsystems align with policy intentions in the energy subsystem depends on the extent to which actors in the land use subsystems espouse beliefs conducive to such outcomes.

According to the ACF, "decisions by sovereigns" (subject to agency resources and general policy orientations) result in policy outputs (Sabatier and Jenkins-Smith 1993:18). "Sovereigns" in a given subsystem include anyone who has decision-making authority for a given policy question and could include bureaucrats, politicians or judges. While ACF research has typically focused on the beliefs of coalitions (Weible et al 2011), doing so has minimized the question of whether some actors' (e.g. sovereigns) beliefs matter more or in different ways than other actors' beliefs in determining policy impacts and outcomes. In regard to the question of subsystem interactions, a focus on the policy impacts (which are a mechanism by which one subsystem can affect another) requires a focus on policy outputs, which are the result of decisions by sovereigns, according to the ACF (Sabatier and Jenkins-Smith 1993:18). Therefore, understanding the beliefs of sovereigns related to the decisions and consequent policy outputs and policy outcomes that have policy impacts on, or affect the ability to realize the policy intentions of, other subsystems is critical to understanding how subsystems interact and, thereby, policy implementation generally. In the case of wind power policy implementation where sovereigns in land use subsystems have at least some degree of autonomy, even if the land use and energy subsystems overlap in terms of some of the actors they encompass, 
the two subsystems will comprise distinct sets of sovereigns with separate areas of authority over wind power policy implementation.

Below is a visual model of the wind power policy process in terms of the dynamics of policy subsystem interactions. The model encompasses the policy subsystems involved in the wind power policy process, including the energy policy subsystem and land use policy subsystems. The constraints and resources of actors in land use subsystems, here termed the institutional framework, are represented as a policy impact of the policy outputs of the energy subsystem. The institutional framework affects the beliefs of sovereigns in the land use subsystems. Likewise, the policy outcome, i.e. whether wind power is developed or not, is represented as a policy impact arising from policy outputs, i.e. whether wind power development is permitted or not, in land use policy subsystems. Finally, policy outputs in both subsystems are represented as the result of the beliefs of sovereigns within those subsystems.

Figure 1. The Dynamics of Policy Subsystem Interactions in The Wind Power Policy Process

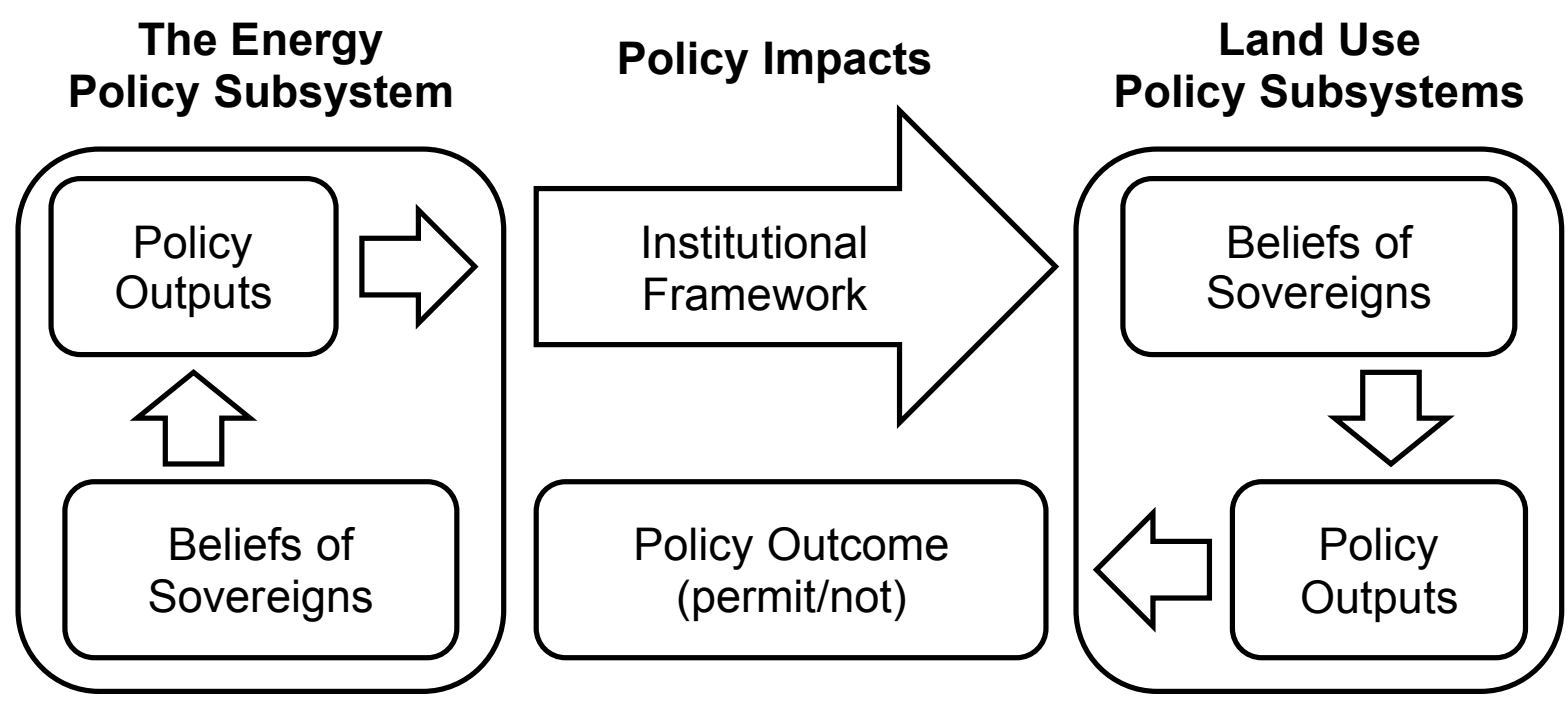

Three things about the model should be noted. First, the model is representative of wind power and potentially other, similar, policy processes in governing systems where the institutional framework grants some degree of autonomy to sovereigns in land use subsystems, thus creating land use subsystems distinct from energy subsystems. Second, where there are multiple, geographically disparate locations where wind power development is a salient issue, there will be multiple land use subsystems involved in the wind power policy process. Each of these subsystems will have the same dynamics, with each being affected by the institutional framework as a policy output of the energy subsystem. Third, wind power policy outputs from land use subsystems ultimately determine the policy outcomes for the wind power policy process as a whole. This last point most clearly demonstrates why the intentions of sovereigns (and consequent policy outputs) in energy subsystems do not always result in the intended policy outcomes, as well as the importance of focusing on the beliefs of sovereigns in land use policy 
subsystems as a key determinant of wind power policy implementation.

\subsection{Research Question and Hypotheses}

Within the aim of this article and the theoretical framework and model outlined above, the research question that will guide the empirical collection and analysis of the case presented in this study is, why do local authorities decide to permit wind power development in situations where 1) national authorities have created institutional frameworks encouraging the development of wind power, yet 2) local authorities have significant discretion concerning wind power development?

Based on this research question, two hypotheses have been derived from the ACF and the framework and model proposed in this article. These hypotheses are applicable to land use policy subsystems where wind power development has been permitted, i.e. where the policy intentions of energy policy subsystem sovereigns have-at least inpart-been successfully implemented at the local level. The hypotheses offer two plausible explanations for why sovereigns in land use policy subsystems might subsume local concerns to national or global ones.

H1: National and global problems (e.g. climate change) and proposed solutions (e.g. developing wind power) are prioritized over local concerns in the beliefs of sovereigns in land use policy subsystems.

This hypothesis is based on the ACF notion that, in order to change policy core beliefs, larger changes, exogenous to the subsystem, are usually necessary. Such changes include changes in the resources attached to or attributes of the policy area of energy policy, including climate change and wind power, and policy decisions and impacts from the energy subsystem (Sabatier and Jenkins-Smith 1993:20, Sabatier and Jenkins-Smith 2007). Of interest here is also within what types of beliefs (i.e. deep core, policy core, secondary) national and global problems and policies would be prioritized, with the ACF postulating that policy core beliefs would be those one would expect to be affected.

H2: National policy goals (i.e. the institutional framework) for wind power development are prioritized over local concerns in the beliefs of sovereigns in land use policy subsystems.

Similar to the hypothesis above, exogenous changes are hypothesized by the ACF to affect policy core beliefs. Institutional frameworks represent changes in the resources attached to or attributes of the policy area of energy policy, climate change and wind power, as well as policy decisions and impacts from the energy subsystem (Sabatier and Jenkins-Smith 1993:20, Sabatier and Jenkins-Smith 2007). H2 contrasts with H1, however, in the sense that policy goals, or institutional frameworks, represent not only attempts to solve national or global problems, but are the rules-of-the-game created by national-level policymakers to induce change in policy outcomes. In other words, a goal to increase renewable energy production as a solution to climate change is one thing, 
while the policies and policy goals by which this solution is to be implemented are another. Climate change is viewed as a global problem, with renewable energy development as a proposed solution. However, in order to realize this solution, policiesusually at the national and sub-national levels promoting, for example, wind power-are necessary. This, in contrast to $\mathrm{H} 1$, which focuses on the degree to which land use subsystem sovereigns prioritize national and global problems and solutions over local concerns, $\mathrm{H} 2$ focuses the degree to which these sovereigns prioritize national policy goals (i.e. the institutional framework) over local concerns. As with H1, of interest is within what types of beliefs institutional frameworks would be prioritized, with the ACF postulating that policy core beliefs would be those one would expect to be affected.

$\mathrm{H} 1$ and $\mathrm{H} 2$ are designed to test whether issues mostly external to land use subsystems are prioritized in the beliefs of sovereigns within those subsystems, as well as what types of beliefs they are prioritized within. In terms of the visual model, the dependent variable is the beliefs of sovereigns in land use policy subsystems. The independent variables include the institutional framework, as well as, more broadly, national and global problems and policies. It could be expected, because wind power development enjoys general support (Jobert et al. 2007, Nadai 2007, Todt 2011) that sovereigns in land use subsystems would be generally in favor of state policies addressing climate change, and other energy-related problems, through developing renewable energy. However, the question of whether to develop wind power in a given land use subsystem, i.e. locally, could be expected to bring differences in beliefs to the fore as specific projects could clash with other land use beliefs and interests. This is yet another reason why it is important to understand the beliefs of sovereigns in cases where wind power projects are actually permitted. General support for the environment, addressing climate change and renewable energy development represent deep core and policy core beliefs whereas beliefs regarding whether and where actual wind power projects should be developed are secondary beliefs.

\section{Research Design}

\subsection{Case}

The aim of this article is to understand why local authorities decide to permit wind power development in situations where national authorities have created institutional frameworks encouraging the development of wind power, yet local authorities have significant discretion concerning wind power development. According to the framework and model developed above in Figure 1, the beliefs (related to wind power development) of sovereigns who have authority for permitting wind power development should be studied. The ideal case for doing this is therefore a case of a land use policy subsystem where 1) the land use subsystem is located within an energy subsystem (i.e. state) with an institutional framework which is intended to encourage the development of wind power and which grants significant local autonomy over land use decisions, 2) sovereigns have permitted the development of wind power, and 3) the permitted 
development would be large enough to have a significant impact on a variety of other existing or potential land uses.

For these reasons, Sweden was chosen as the country within which to study land use policy subsystems and wind power development. In consequence of the EU's renewable energy goals and targets, and as a result of their own domestic policy goals for renewable energy development, national-level policymakers in Sweden have undertaken to develop policy intended to spur the growth of renewable energy development, including wind power, in the country. Since the early 1990s, when there was very little wind power, increases in wind power production yearly have grown five-fold. Some of the most ambitious wind power projects in Europe have also been undertaken in Sweden. Indeed, there have been a number of significant policies in Sweden aimed at developing wind power, and those policies have resulted in a significant policy outcome in the form of massive increases in wind power production. From the perspective of furthering the development of renewable and wind energy production, this alone makes Sweden an interesting case.

Sweden is also a good example of the separation of authority between the national/regional governments and local governments when it comes to wind power development. In Sweden, there is a long-standing and strong tradition of municipal autonomy, which extends to wind power and which goes so far as to afford municipalities a de facto veto over wind power development within their borders. Because of this, Sweden provides an interesting context from which to understand why it is that wind power is developed at all in a context where the benefits of such development are often global while the costs are usually local. This is because when it comes to wind power most of the benefits (electricity produced, carbon emissions reduced, and increased energy independence) are accrued at the national or even global level rather than the local level. While municipalities may anticipate increased local economic development, wind power projects, which take a large amount of land-area, can easily interfere with other actual and potential land uses such as housing, recreation, forestry, etc. This means that most of the negative effects of wind power development are observed locally. It is therefore interesting to try to understand why municipal authorities make the decision to allow wind power developments when they need not do so.

While wind power developments have proceeded in many cases in Sweden, as evidenced by the large increase in wind power production in the last 25 years, success in developing new projects is far from guaranteed. Wind power projects across Sweden have been rejected by municipalities for reasons ranging from developers' requests to build outside areas designated by the municipality for wind power development (Falköpingstidning 16 December 2014) to interference with airport landing zones (Lerumstidning 26 February 2014) to protecting landscape aesthetics (Helsingborgs Dagblad 7 April 2005). When developers appeal municipal decisions to regional authorities, municipalities' decisions are usually upheld, reinforcing municipal autonomy. Given that the costs of wind power development are mostly local and given that many benefits, such as reducing greenhouse gas emissions and producing electricity are often regional, national, or global, it is interesting that municipalities approve such projects at all. While local economic development is certainly one motivating factor, wind power 
companies often import expertise and materials; furthermore, wind power projects can directly threaten some economic, environmental, and other societal interests of the local population, such as preserving the landscape, reindeer herding, forestry, etc. The most interesting cases to look at would therefore be cases where municipalities did approve the building of wind power developments, especially large developments that would have a significant impact on land use, which would thus force land use subsystem sovereigns to make political decisions involving value conflicts when they did not have to, given their de facto veto over such projects.

The land use subsystem selected within the Swedish context is within the Pitea Municipality, with a focus on the Markbygden wind power project. The Markbygden wind power project is a development that, if all phases of development are permitted and completed, will end up being one of the largest wind parks in Europe. After the area was identified by the Swedish national government as a strategically important area for wind power development during the early 2000s, the company "Markbygden Vind" began to explore the possibilities for developing wind power projects in the area. By 2009, permissions had been granted for a pilot project, and 12 turbines had been erected. A second pilot project comprising 8 turbines was permitted and complete by 2011. Following the development of the pilot projects, it was determined by the interested companies that a three-phase project comprising 1101 turbines up to 200 meters high could be developed. This project, when completed, would cover 450 square kilometers (more than twice the size of Stockholm Municipality), and produce about 10TWH a year, or $6.6 \%$ of Sweden's total electricity production. In 2012, Phase 1, comprising a little over 314 turbines, had received the necessary permissions. In 2015, Phase 2 was approved and the building rights were subsequently sold to Enercon. The third Phase is still being evaluated and investigated at this time.

The permitting process for the construction of a project of this magnitude, including the pilot projects, comprises essentially four steps. First, the Environment and Building Committee of the Municipal Council investigates the issue in depth, including its impact on residents, the environment, and other interests involved, and decides whether to grant a building permit. Second, for a project of this size, the areas proposed for development must also be included in the Municipality's Comprehensive Plan, which is voted on by the entire Municipal Council. Third, providing that Municipal permits and approval are secured, the project is sent to the County Administrative Board for an environmental permit. After conducting an environmental impact assessment of the proposed project, the Board votes on whether to grant its permission. Finally, because of the size of the project, and its potential conflicts with national interests, such as military over-flights, the National Government must grant its permission for the project. As noted earlier, both of the Markbygden pilot projects, as well as the first two phases of the main Markbygden project have received the necessary permits and approvals, while the third phase is still under investigation. The focus of this case study, however, will be on the political decisions made by the Piteå Municipality to permit and approve the project, as opposed to the decisions made by the County Administrative Board or the National Government.

Because of the structure of this permitting and approval process, Municipalities in 
Sweden have an enormous amount of autonomy in deciding whether to allow wind power development within their boundaries. While developers can, in theory, appeal municipal decisions to the County Administrative Board or National Government, in practice, the regional and national governments defer to local decisions. Therefore, in order for a project to stand any real chance of realization, local approval must be secured. For these reasons, the case study will be a study of the political decisions made at the local level in the land use policy subsystem, in this case, in Piteå Municipality. Piteå Municipality was chosen, in part, because while the area for development is sparsely populated (about 400 residents in the area), there are a number of potential local-level conflicts with the development. These include the forestry industry, industrial quarries, reindeer herding by the indigenous Sami, numerous summer homes and the aforementioned residents, as well as large hunting and recreation areas. Because the development of the project would entail not only the construction of the massive turbines and their foundations, but also the building of their foundations and the necessary service roads, the impact from the project would be large, giving rise to the potential for value conflicts for the municipal sovereigns seeking to balance the competing needs, wants and interests of their constituents, as well as their own values and beliefs. The enormity of the project-as opposed to a smaller development with only a few turbines - exacerbates such conflicts. Piteå Municipality therefore serves as an excellent case for examining the political decisions made, and the values, beliefs, and value conflicts behind those decisions.

The critical political decision made at the local level was the decision to include the Markbygden project in the Municipal Comprehensive Plan, the precursor to all subsequent development planning decisions within the municipality, and the basis for proceeding with the project's development. In the first half of 2005, public consultation meetings were held in the villages in the area that would be affected by the project. A proposal for the Comprehensive Plan was subsequently displayed in the city hall, the city library, and larger villages in the area during the second half of 2005, during which time comments on and suggestions for changes in the plan were received. During 2006, the plan was revised; it was then approved by the City Council Board in January of 2007. From April to June of 2007, the new plan was again displayed in the aforementioned places throughout the municipality. On December $17^{\text {th }}, 2007$, the Municipal Council voted to adopt the Comprehensive Plan, including areas designated for the development of Phase 1 of the Markbygden project.

As might be assumed, the process leading up to the decision was contentious. Despite concessions made in the plan to increase the minimum distances between turbines and homes, local nature conservation group property owners were expressly against the development, citing the impact it would have on the landscape aesthetic and on those living in the area because of the shadows cast and the noise made by the turbines. The two main associations representing hunters in the areas were divided with one group in favor and one against. The Swedish Ministry of Defense also expressed its reservations regarding the impact the turbines would have on an area used for airborne military exercises. The Sami also expressed some concerns regarding the impact the turbines and service roads would have on areas used for reindeer herding and migration, but the Municipality noted that these concerns were chiefly a question of national 
interests and not of concern to the Municipality itself. The large majority of municipal officials, i.e. the subsystem's sovereigns, on the other hand, were quite favorable toward the development, despite opposition. This therefore presents an interesting case for exploring the value conflicts of sovereigns and how they weighed their various, competing values (e.g. the opposition of certain constituents vs. their desire to approve the project) in relation to their political decision to approve the Markbygden project in 2007.

\subsection{Data Collection and Methods}

In the case of specific wind power developments, sovereigns are those that have jurisdiction over wind power planning and authority to approve areas within their geographic area of jurisdiction for wind power exploration and development. In Sweden, this includes the Representatives of the elected Municipal Council, who vote on such plans, as well as municipal and county bureaucrats who are involved in the planning process and consult with project developers. To study the beliefs of sovereigns, a mix of qualitative (media and document analysis) and quantitative (survey) methods were used.

In order to assess the beliefs of sovereigns regarding the decision to permit the Markbygden wind power project, two methods and three data sources were used. Text analysis of major newspaper articles containing statements by land use policy subsystem sovereigns as well as documents containing sovereigns' responses to public comments on the project was done. A survey was also sent out to sovereigns to directly assess their beliefs related to the decision to permit the project. Because of the large number of sovereigns involved (over 60), it was deemed unfeasible to strategically choose and then conduct a sufficient number of individual interviews to capture the wide range and diversity of interests, opinions and beliefs that sovereigns held in relation to the decision to permit the project.

To find the news articles, the three major newspapers in the region were searched for articles dealing with the project and in which sovereigns had made statements. Thirtyfour such articles were found. The time span covered was from the first article mentioning the project up until the decision was made by the Municipal Council to approve the Comprehensive Plan for Rural Areas in December 2007. The media articles were complemented with official documents of meetings held and reports generated and used by the Municipal Council Representatives to evaluate, plan for and decide on the Markbygden project. The document containing the relevant information was the report to the Municipal Council on the statements and opinions (dealing with problems and reservations about the project) made by individuals and groups in relation to the thenproposed Comprehensive Plan for Rural Areas. This report included the official responses/comments of the Municipal Council to the opinions and statements made.

The media articles and documents were analyzed using qualitative idea(sometimes referred to as ideology-) analysis. Idea-analysis is predominantly used for identifying the values, ideologies and belief-systems of an actor, in a policy area or in a debate, and has previously been applied in tracing ideas in political debates as well as in 
mapping and analyzing ideological development among groups of actors (Esaiasson et al, 2004, Bergström and Boréus, 2005). Idea-analysis is also qualitative in character since it aims at exploring the ideas, values or beliefs in, for instance, written texts, and not to quantify the use of language itself. I agree with Devine's (2002:207) conclusion that the qualitative methods' advantages "are clear where the goal of a piece of research is to explore people's experiences, practices, values and attitudes in depth and to establish their meaning for those concerned." All quotes from articles and documents are translations from Swedish by the article's author and are selections that are illustrative of the beliefs expressed generally.

To further assess and validate the beliefs of sovereigns observed in the media statements and documents, a survey was sent to 63 of the Municipal Council Representatives and Substitutes-18 filled out the survey for a response rate of $28.6 \%$. Because of the small population being sampled and due to the response rate, the results were analyzed using descriptive statistical measures only, and were used-together with the analyses of media articles and official documents - as a means of triangulating the beliefs of sovereigns.

Prior to the sending out the survey, and in order to determine what specific land-use concerns were at stake in approving the Markbygden area for wind power development, other studies and documents were consulted, and two pilot interviews with Representatives of the Municipal Council from different political parties were conducted. The interviews also served as a means of cross-validating the results of the survey. The survey asked the respondents questions about how important various concerns related to wind power development were to them. Some of the concerns were specific to local wind power development and some were relevant to wind power development on a national or global scale. The following is the list of concerns:

1. Solving national and global problems, such as climate change

2. Solving climate change through producing more renewable energy

3. Achieving Sweden's national policy of developing renewable energy, including wind power

4. Creating economic growth

5. Creating jobs

6. Protecting the natural environment

7. Protecting wild animals and plants

8. Preserving a peaceful and undisturbed environment for residents

The first three concerns are, for the most part, issues external to land use subsystems, with the first two being global in nature and the third representing the national institutional framework within which land use subsystems operate. Concerns 4-8 are, in contrast, mostly local in nature and within the purview of land use subsystems. Respondents were asked to rank how important they felt these concerns were on a scale from Very Unimportant, Somewhat Unimportant, Neither Important Nor Unimportant, Somewhat Important to Very Important. Furthermore, the questions were posed according 
to how important they felt about them generally (i.e. in terms of deep core beliefs), in terms of municipalities in general (i.e. policy core beliefs), and in terms of how they felt about them in regard to the Markbygden project specifically (i.e. secondary beliefs). Respondents were also asked whether they voted for or against the Comprehensive Plan, which demarcated the Markbygden area for wind power development. The following questions were used to assess the types of beliefs:

DEEP CORE: How important are the following [issues] for you? E.g. creating economic growth.

POLICY CORE: How important is it that INDIVIDUAL MUNICIPALITIES do the following? E.g. create a favorable environment for economic growth in the municipality.

SECONDARY: How important were the following factors in your decision to be "for" or "against" (in the Comprehensive Plan for Rural Areas) designating Markbygden as an appropriate geographic area for wind power development? E.g. that the Municipality should create a favorable environment for economic growth in the Municipality.

Concerns 1-3 are factors essentially external to land use subsystems, while factors 4-8 are more internal to them. If institutional frameworks created by national governments influence the beliefs of sovereigns in land use subsystems, then one would expect that concerns 1-3 (particularly concern 3) would be rated as relatively important, especially at the level of secondary beliefs. On the other hand, if global and national concerns and institutional frameworks have little influence on the beliefs of sovereigns in land use subsystems, then one might expect to see some support for concerns 1-3 at the deep core or policy levels, but perhaps less at the secondary level, where such concerns are weighed against local concerns 6-7. In the case of Piteå, where the wind power development was approved, concerns 4-5 could also play a mitigating role between the potentially negative impacts of wind power development locally and the positive impacts nationally and globally; if sovereigns view economic growth and employment as very important relative to concerns about negative local impacts, it could explain why they approved the development of wind power in Markbygden.

The use of media statements, official documents and the survey enabled the beliefs of sovereigns to be triangulated, as well as allowing the results of each dataset to be cross-validated. Thus, a more accurate picture of the relevant beliefs emerged than would have been possible if relying on only one source of data. When studying land use policy subsystems, the multi-data source approach to assessing the beliefs of sovereigns is particularly important because most sovereigns in land use policy subsystems are local politicians and bureaucrats and documentation and media coverage of their expressed beliefs are not nearly as abundant or readily accessible as, for example, those of national politicians. Also, while all of the methods aim to obtain information on the beliefs of sovereigns, the survey does so in a way that is designed to most explicitly delineate between the different interests sovereigns face and the types of beliefs they hold. 
Therefore, the media articles and documents will serve to provide a map of the relevant beliefs, as well as a way of validating the assumptions and results of the survey. The survey itself will then provide the most explicit account of how sovereigns prioritize the different beliefs they hold, as well as at what level/within which type of beliefs (deep core, policy core, secondary) sovereigns make these prioritizations.

\section{Results}

\subsection{Media Articles}

In order to assess the prioritization of beliefs among sovereigns in the Pitea area land use subsystem regarding the Markbygden wind power project, the three major newspapers in the area were searched for articles dealing with the project where sovereigns' beliefs were expressed. The time span was from the first articles mentioning the project up until the decision was made by the Municipal Council to approve the Comprehensive Plan for Rural Areas. The sovereigns who expressed themselves in the media included, in addition to various Representatives of the Municipal Council, the Mayor of Piteå, the Governor of Norrbotten County, the Director of the Office of Economic Development for Piteå Municipality, and the Office of Environment and Construction for Piteå Municipality. The quotes presented here focus on the prioritizations that sovereigns made between competing beliefs/concerns.

Most notably, almost all of the sovereigns were positive about the project, for various reasons. The county Governor, after learning of the potential project said: We are going to be the new oil sheiks (Kuriren 1).... An expansion of wind power is important for Norrbotten and for Sweden. It contributes to sustainable development. There is also growth potential for wind power as an industry (Kuriren 2).

Municipal officials hailed the project as: A great chance for many new jobs, good economic development and a good environment (PT 1)... For the municipality, it is like discovering a gold mine. If this becomes a reality, it will be like winning the lottery for Pitea and the whole region (PT 2)...[The Markybygden project] constitutes an important part of realizing the country's energy transformation (Kuriren 3).

Municipal Council Representatives were similarly enthusiastic:

For the Pitea countryside, many needed jobs will result and interest in creating new businesses will increase. Access to environmentally friendly energy will greatly impact increased economic development in all of Norrbotten (PT 3) The climate threat is global, but emissions are local... How do you think we are going to address the temperature increases in the atmosphere? (PT 4) ... [This development]...will lead to more electrical energy and put more pressure on prices, but mostly will produce electricity in an environmentally friendly way. As the cherry-on-top, jobs will be created for a period of time (PT 5).

The optimism expressed by these sovereigns was chiefly concerning the effects 
the project would have on local economic development and jobs (local concerns), climate change (a global problem), and Sweden's energy policy (the institutional framework), rather than the local residents or local environment (other local concerns). The only sovereign who was covered in a news article who was not optimistic was a Municipal Council Representative, who raised several concerns:

The negatives associated with wind power projects weigh heavily, if you look closely. I suggest that the reference group [studying the project] starts their work over and presents the downsides of wind power and not just put everything in a positive light. As things are now, it looks as if we are digging a large hole in Markbygden's future that will become its grave with the wind power park. House prices will fall and fewer people will move in. Who wants to live in an area with a wind power park that is both noisy and that ruins the environment and hunting? Don't be naive and think that there will be many more jobs. The wind power company will bring in their own people, who cost less. The local or regional workforce will not be employed because they lack the competence and experience (PT 6).

This statement clearly prioritizes the issues of protecting the (local) environment and the impact the project will have on local residents, while being skeptical to whether the project would positively impact the local economy and jobs.

Other sovereigns recognized some of these concerns, but the concerns were mostly either relegated to technical (i.e. secondary belief) status - e.g. making small adjustments to the plans-or they were deprioritized compared to other policy concerns-like economic growth and climate change- outright. For example, concerning the appeals on the decision to approve the project, one municipal official said: Of course we should respect individuals' interests, but by appealing at multiple steps and instances, the process is being prolonged too much (PT 7). Similarly, the Governor for Norrbotten County said:

Many believe that [wind power] ruins the landscape and that it isn't beautiful from an environmental perspective. We should, of course, respect that. But I also believe that we should learn to think "wind power." Norrbotten has a responsibility to think about the global environment. We can all see the effects of climate change (PT 8)... You need to weight different national interests against each other and then make a decision... We are unused to wind power in Norrbotten. Many say that it ruins the landscape. Once upon a time there was a debate about forbidding highways (Kuriren 1).

And along the same lines, the Mayor of Piteå said: There are downsides to everything, if you are naive. Tourism is, for example, an important industry for us. But I don't see any conflicts between tourism and the wind park plans which are being discussed today (PT 1). A Municipal Council Representative also said: Of course, it will be an adjustment. But the pros outweigh the cons. The world needs environmentally friendly energy and Markbygden needs development, something which the project will further... I 
will learn to accept wind power...[I don't] see any dangers for wildlife (PT 9).

The beliefs expressed by the sovereigns were overwhelmingly in favor of the project. Where there were reservations, these were deprioritized compared to the following policy concerns: economic growth and jobs (local concerns), addressing climate change (a global problem) and supporting Sweden's renewable energy policy (the institutional framework). When weighing these concerns, some sovereigns went so far as to express the primary importance of addressing climate change over local concerns generally. Others spoke mostly of the economic benefits and jobs, and others viewed the project as a winwin situation for climate change/Sweden's renewable energy policy and local economic growth/jobs. With the exception of a single skeptical sovereign, concerns about the local environmental impact, and the impact on wildlife, plants and the impact on local residents were minimized. Another interesting fact was that there was not a lack of vocal opposition to the project in Piteå. Hunter's groups, local residents and others were opposed and/or were skeptical to the project. However, these beliefs were evidently shared by only a small minority of sovereigns. This latter point emphasizes the importance of studying the beliefs of sovereigns in particular, compared to the beliefs of policy subsystem actors in general.

\subsection{Meeting Documents}

The second type of material that was used to assess the beliefs of sovereigns and how they prioritize them was the documents of the meetings and reports used by the Municipal Council Representatives of Piteå to evaluate, plan for and decide on the project. The document containing the most relevant information was the report to the Municipal Council on the statements and opinions (dealing with problems and reservations about the project) raised by individuals and groups in relation to the Comprehensive Plan for Rural Areas. This report included the responses/comments of the Municipal Council to the opinions and statements made. The following is exemplary of the responses and covers all of the issues and trade-offs addresses in the document:

The municipality has adjusted the [wind power] exploration area...so that the distance between the buildings and the exploration area will be between 12001500 meters. Through the now increased distance between the buildings and the planned wind power park, it is judged that no disturbances in the form of noise, shadows, or reflections will occur. Generally, it can be said that all forms of wind power construction affect the landscape. The Municipality is aware that there are different opinions on whether this change in the landscape is good or bad. The Municipality has taken into account a number of the pros and cons of a large project such as this. The project, if it is implemented to the extent planned, will contribute to increasing the supply of renewable energy in the country significantly. The project will create new jobs...In this case the municipality judges that the area should be used for wind power because this land use works well when combined with forestry. The project will be implemented in phases and in coordination with the implementation of the respective stages of the project, the environmental impact of those stages will be assessed... The project will be done 
in such a way that waterways will not be affected and so that the effects on plants and animal life will be minimized... The Municipality judges that the wind power project, if it is implemented, will affect property values positively (Piteå Kommun 2007).

Rather than questioning the viability of the project as a whole, technical concessions are made, e.g. increasing the distance between the wind park and buildings. It is recognized that wind power impacts the landscape and that there are varying opinions on whether this is good or bad, but goes on to dismiss local concerns in favor of "[contributing] to increasing the supply of renewable energy in the country significantly (a national policy goal/the institutional framework). New jobs and property values (local concerns) are cited as positives, while impacts on the local environment (another local concern) are noted as issues to be assessed and something that will be minimized, but are not addressed as issues important enough to warrant reconsidering the viability of the project as a whole. As in the media articles, it is clear that the concerns raised by individuals and groups are dealt with in one of two ways. First, some concerns are relegated to the status of technical concerns (i.e. secondary beliefs) that can be dealt with by making technical adjustments, but without changing the policy beliefs concerning the project as a whole. Second, where there is a recognition of some of the negative impacts of the projects, these are noted, but dismissed as less important compared to the overall positive impacts of the project, such as on the local economy and Sweden's renewable energy supply (i.e. the institutional framework).

\subsection{Survey}

Finally, a survey of Municipal Representatives and Substitutes was used to further assist in triangulating how sovereigns prioritized their beliefs. Table 1 displays the results of the survey. The eight areas of concern are listed horizontally across the top. The lefthand column displays how each concern is ranked by type of belief-deep core, policy core or secondary. The concerns were scored from 1-5, from 1 being Very Unimportant to 5 being Very Important. Of those surveyed, $72.2 \%$ voted for the "Comprehensive Plan for Rural Areas, " $11.1 \%$ voted against, and $16.7 \%$ did not vote. Because there were so few who voted against the plan, and because there was no clear trends among those who voted against it, their results were not separated out from the other groups. The first three concerns-1) national and global problems, such as climate change, 2) solving climate change through producing more renewable energy (a proposed solution to said problems), and 3) achieving Sweden's national policy of developing renewable energy, including wind power (the institutional framework) - are concerns external to land use subsystems, or those which do not (at least directly) affect the specific subsystem itself. The last four-4) creating economic growth, 5) creating jobs, 6) protecting the natural environment, 7) protecting wild animals and plants, and 8) preserving a peaceful and undisturbed environment for residents - are concerns internal to land use subsystems, or those which affect the specific land use subsystem directly. 
Table 1. Results of Survey of Municipal Council Representatives and Substitutes

\begin{tabular}{|c|c|c|c|c|c|c|c|c|}
\hline $\begin{array}{l}\text { Concern Scor } \\
\text { Pretty Importa }\end{array}$ & $\begin{array}{l}\text { : 1) Very L } \\
\text { 5) Very In }\end{array}$ & $\begin{array}{l}\text { Inimporta } \\
\text { portant }\end{array}$ & 2) Pretty & nimpor & 3) $\mathrm{N}$ & $\operatorname{Impc}$ & Nor & nportant 4) \\
\hline Belief Types: & $\begin{array}{l}\text { nat/glob } \\
\text { problms } \\
\text { e.g. climt } \\
\text { chng }\end{array}$ & $\begin{array}{c}\text { solve } \\
\text { climt via } \\
\text { renwbl } \\
\text { energy }\end{array}$ & $\begin{array}{l}\text { Swedish } \\
\text { renwbl } \\
\text { policy, } \\
\text { incl wind }\end{array}$ & $\begin{array}{l}\text { econ } \\
\text { growth }\end{array}$ & jobs & $\begin{array}{l}\text { protect } \\
\text { environ }\end{array}$ & $\begin{array}{l}\text { protect } \\
\text { animal/ } \\
\text { plant }\end{array}$ & $\begin{array}{l}\text { preserve } \\
\text { environ for } \\
\text { residents }\end{array}$ \\
\hline $\begin{array}{l}\text { General } \\
\text { Importance } \\
\text { (deep core) }\end{array}$ & 4.06 & 4.17 & 4.00 & 4.17 & 4.39 & 3.78 & 3.78 & 3.56 \\
\hline $\begin{array}{l}\text { Individual } \\
\text { Municipalities } \\
\text { (policy core) }\end{array}$ & 3.83 & 3.82 & 3.89 & 4.28 & 4.44 & 3.75 & 3.88 & 3.65 \\
\hline $\begin{array}{l}\text { In } \\
\text { Markbygden } \\
\text { (secondary) }\end{array}$ & 3.72 & 3.88 & 3.94 & 4.00 & 4.00 & 3.44 & 3.56 & 3.44 \\
\hline
\end{tabular}

At the general level - that is, at the deep core level of general, non-policy-specific beliefs - national/global problems, solving climate change and Swedish renewable energy policy (i.e. the external concerns) are prioritized highest among land use subsystem concerns, except for economic growth and jobs, which are prioritized higher than all external concerns. This is mostly true concerning the priorities for municipalities (i.e. at the policy level) as well, with the sole exception being protecting animals and plants. When it comes to the secondary level (i.e. concerning the Markbygden wind project specifically), the trend is the same, with economic growth and jobs coming first, prioritized ahead of the external concerns, which are, in turn, prioritized above protecting the environment, protecting animals and plants, and preserving the environment for residents. The results concerning secondary beliefs are particularly interesting because this is where one would expect local environmental concerns to be most prioritized over more general concerns, either because of the NIMBY phenomenon or simply because of concrete, competing interests. Yet, it is at the secondary level of belief that local environmental concerns are least pronounced, compared to the policy core- and deep belief-levels. The conclusion that can be drawn from these results is that, generally speaking, economic growth and jobs are viewed as the highest priority by municipal officials (perhaps not surprisingly), but concerns external to land use subsystems (global problems, developing renewable energy, and achieving Sweden's renewable energy goals) were prioritized above concerns about the local environment and effects on local residents.

\section{Discussion}


The aim of this article was to understand why local authorities decide to permit wind power development in situations where 1) national authorities have created institutional frameworks encouraging the development of wind power, yet 2) local authorities have significant discretion concerning wind power development. To achieve this aim, a theoretical model was developed that explains the interaction of the energy policy subsystem and land use policy subsystems in terms of institutional frameworks, the beliefs of sovereigns, policy outputs and policy outcomes. Based on this model, two hypotheses concerning what influences local sovereigns, and their beliefs, were derived and then tested using a case of successful wind power development. Concerning the hypothesis that sovereigns in land use policy subsystems who would approve wind power projects would favor national and global concerns and policies over local issues, the results are mixed. With the exception of the few sovereigns who were negative to the project, most of the sovereigns prioritized four concerns over others: climate change, Sweden's renewable energy policy/the institutional framework (both concerns external to the land use subsystem), and local economic growth and local jobs (concerns internal to the subsystem). Some sovereigns explicitly prioritized climate change and Sweden's policy/goals over all local concerns, whereas in the survey, as well as in some of the statements by sovereigns, sovereigns appear to prioritize local economic growth and jobs first. Other sovereigns seem to view these factors as a win-win situation. What can be said, in relation to the hypothesis, is that national and global concerns and policies (external concerns) are prioritized over some internal concerns in the beliefs of sovereigns, including concerns about protecting the local environment, local animals and plants and local residents. At the secondary belief level this prioritization is most clear, but even at the policy and deep core belief levels, the effect is present.

For the second hypothesis that sovereigns in land use subsystems would prioritize national policies and goals for wind power development over local concerns, as with the first hypothesis, there is partial support. Some sovereigns prioritize the institutional framework (i.e. Swedish energy policy, a concern external to the subsystem) over all local (internal) concerns, while others seem to view it on-par or below concerns about local economic growth and jobs. But, it is quite apparent that Swedish policy is prioritized over the local environment, local animals and plants and local residents. This is most pronounced at the level of secondary beliefs, but is also present at the policy and deep core belief levels.

The guiding research question of this study was: Why do local authorities decide to permit wind power development in situations where 1) national authorities have created institutional frameworks encouraging the development of wind power, yet 2) local authorities have significant discretion concerning wind power development? In answer to this question, in the case of Piteå Municipality approving a large wind project, local authorities (sovereigns) appear to have decided to permit the project because they believed in the importance of addressing climate change, as well as supporting Swedish renewable energy policy (concerns external to the land use subsystem), but also because they believed the project would yield local benefits, in terms of economic growth and jobs. In their decision, it was apparent that authorities did not believe that concerns about the impact the project would have on the local environment, local animals and plants and 
local residents were of relative importance. Rather, these issues could be dealt with by making small, technical adjustments to the planned project.

\section{Conclusions}

In developing a model for understanding how policy subsystems interact that focuses on the role of sovereigns and how they are influenced by factors external to their policy subsystems, this article has elucidated the mechanisms by which the national and local levels, or in this case, the energy policy and land use subsystems, can affect each other. This model thus provides an explanation for why wind power policy implementation was successful in the case studied here.

From this model, two hypotheses were derived. The results from analyzing the case of Pitea with the help of the model have furthered the aim of the article through shedding light on the beliefs of the sovereigns who make decisions about policy outputs, but more importantly, how sovereigns prioritize between their conflicting beliefs. The analysis of the results from the case indicated partial support for both hypotheses, with prioritization being given to climate change, Swedish policies, local economic growth and jobs over concerns about the local environment, local animals and plants, and local residents. This could indicate a differentiation by sovereigns between the types of beliefs and concerns internal to land use subsystems. It is possible that local concerns about the economy are viewed as more or similarly important to concerns external to the subsystem, such as climate change and national energy policy goals. In contrast, concerns about impacts on the local environment, wild and plant life and local residents were not viewed as important as concerns external to the land use subsystem. This is interesting because land use subsystem sovereigns would not necessarily be expected to prioritize concerns external to their subsystem because external concerns do not directly impact their policy sphere, local interests, local reelection prospects, etc. in the same way that local concerns, such as upsetting local residents, would. Yet in this case, sovereigns did prioritize external concerns over some types of local concerns. When and why sovereigns prioritize external concerns over local ones is worth examining further because of the implications this has for policy implementation research and practice.

This article has also highlighted the importance of studying sovereign beliefs within the context of the ACF and policy implementation more generally. Sovereign beliefs are apparently not always representative of subsystem beliefs in general and because of the role sovereigns have in formulating policy outputs, their beliefs warrant special attention. This article has posited, in the form of a theoretical model, that one factor that affects sovereign beliefs in land use subsystems (and perhaps other, more locally based subsystems) is the institutional framework, or national policies and goals. The results of this study have provided some support for this proposition. Further examination of the effects that institutional frameworks, as well as other factors, have on the beliefs and prioritizations of beliefs of local-level sovereigns is therefore also warranted, as does the more general question of how subsystems interact and influence each other. Of particular interest is the role that land use policy subsystems play in the 
implementation of national or international policies that impact land use on the local level, such as energy and natural resource development, resource extraction, environmental protection, etc.

In contrast to previous empirical studies of renewable energy and wind power policy and implementation, this approach offers two things. The first is a model that offers a theoretically coherent way to integrate analyses of national policy processes with regional/local policy processes, rather than analyzing such processes discretely. Indeed, the approach proposed here suggests that the discrete analyses of the different policy subsystems involved in wind power development (and potentially other areas) that have been done to-date might miss important explanatory factors. These factors include not only beliefs, but also policy subsystem-interaction effects on sovereigns' beliefs. Second, this approach offers a way to utilize policy subsystem theory in general, and ACF theory in specific, to delineate and study wind power policy in a way that accounts for multiple subsystems and levels of wind power policymaking, something that has yet to be done in a theoretically systematic way. Finally, the model proposed offers a theoretical contribution to the emerging (yet scant) literature on policy subsystem interactions, an area of inquiry that promises a way to more fully account for policy making in spheres that, by their nature, cross traditional policy subsystem boundaries. The theoretical developments proposed here offer a (rough) map as to how to proceed in addressing such questions. 


\section{References}

Agterbosch, S. Breukers, S. (2008) "Socio-political embedding of onshore wind power in the Netherlands and North Rhine-Westphalia" Technology Analysis and Strategic Management 20(5): 633-648.

Baumgartner, F. Jones, B. (1993). Agendas and Instability in American Politics Chicago: University of Chicago Press.

Bergström, G., Boréus, K. (2005) Textens mening och makt. Lund: Studentlitteratur.

Berkes, F. (2002). "Cross-Scale Institutional Linkages: Perspectives from the Bottom Up" In Ostrom, E. et al. (Eds.) The Drama of the Commons. Washington, D.C.: National Academy Press (pp. 293-323).

Breukers, S. Wolsink, M. (2007) "Wind power implementation in changing institutional landscapes: An international comparison" Energy Policy 35: 2737-2750.

Clement, F. (2010) "Analysing decentralised natural resource governance: proposition for a "politicised" institutional analysis and development framework" Policy Sciences 43: 129-156.

Davidsson, A. (7 April 2005) "Dyrt och sent avslag för vindkraft" Helsingborgs Dagblad

Accessed at: http://www.hd.se/2005-04-07/dyrt-och-sent-avslag-for-vindkraft on 17 February 2017.

Devine, F. (2002) Qualitative methods. Theory and methods in political science. 2: 197215. New York: Palgrave Macmillan.

Devine-Wright, P. (2005) "Local aspects of UK renewable energy development: exploring public beliefs and policy implications" Local Environment: The International Journal of Justice and Sustainability 10(1): 57-69.

Ek, K., Persson, L., Johansson, M. and Waldo, Å. (2013). "Location of Swedish wind power: random or not? A quantitative analysis of differences in installed wind power capacity across Swedish municipalities." Energy Policy, 58: 135-141.

Esaiasson, P., Gilljam, M., Oscarsson, H., Wängnerud, L. (eds.) (2004) Metodpraktikan Konsten att studera samhälle, individ och marknad. Stockholm: Norstedts juridik.

European Commission. (2014) The 2020 climate and energy package. Accessed at: http://ec.europa.eu/clima/policies/package/index en.htm on 2014-05-29.

European Union (2013) "Summary of the Member State Forecast Documents." Accessed at:

http://ec.europa.eu/energy/renewables/transparency_platform/doc/dir_2009_0028_arti cle_4_3 forecast by_ms_symmary.pdf on 7 November 2014.

European Union (2014) "2030 Framework for Climate and Energy Policies." Accessed at http://ec.europa.eu/clima/policies/2030/index_en.htm on 7 November 2014.

Falköpingstidning (16 December 2014) Avslag för vindkraft. Accessed at:

http://www.falkopingstidning.se/article/avslag-for-vindkraft/ on 17 February 2017.

Ferguson-Martin, C. Hill, S. (2011) "Accounting for Variation in Wind Deployment Between Canadian Provinces” Energy Policy 39(3): 1647-1658.

Hooghe, L. and G. Marks (2003) "Unravelling the Central State - But How? Types of Multi-level Governance" American Political Science Review 97(2): 233-243. 
Imperial, M. (2005). "Using Collaboration as a Governance Strategy" Administration and Society 37(3): 281-320.

International Energy Agency (IEA) (2007). Tackling Investment Challenges in Power Generation, OECD, Paris.

International Energy Agency (IEA) (2015) International Renewable Energy Policies and

Measures.Accessed online at:

http://www.iea.org/policiesandmeasures/renewableenergy/?country=Sweden

Jegen, M. Audet, G. (2011) "Advocacy coalitions and wind power development: Insights from Quebec” Energy Policy 39: 7439-7447.

Jobert, A. Laborgne, P. Mimler, S. (2007) "Local acceptance of wind energy: Factors of success identified in French and German case studies" Energy Policy 35: 2751-2760. Jochim, A. May, P. (2010) "Beyond Subsystems: Policy Regimes and Governance" Policy Studies Journal 38(2): 303-327.

Jones, M. Jenkins-Smith, H. (2009) “Trans-Subsystem Dynamics: Policy Topography, Mass Opinion, and Policy Change" The Policy Studies Journal 37(1): 37-58.

Khan, J. (2003) "Wind Power Planning in Three Swedish Municipalities" Journal of

Environmental Planning and Management 46(4): 563-581.

Kuriren (Kuriren 1). "Hövdingen vill sätta snurr på länet" 2007-03-31.

Kuriren (Kuriren 2). "Ja till tolv vindsnurror" 2007-12-20.

Kuriren (Kuriren 3). "Ja till vindkraft" 2007-08-17.

Kuriren (Kuriren 4). "Första steget mot vindkraftpark" 2007-12-21.

Lerumstidning (26 February 2014) Ingen vindkraftspark på Nääs. Accessed at: http://www.lerumstidning.se/2014/02/ingen-vindkraftspark-pa-naas/ on 17 February 2017.

Lundqvist, L. (2004) Sweden and Ecological Governance: Straddling the Fence. Manchester University Press.

Matland, R. "Synthesizing the Implementation Literature: The Ambiguity-Conflict Model of Policy Implementation" Journal of Public Administration Research and Theory 5:2: $145-174$.

May, P. Sapotichne, J. Workman, S. (2009) "Widespread Policy Disruption: Terrorism, Public Risks, and Homeland Security” The Policy Studies Journal 37(2): 171-194.

McLaren Loring, J. (2007) "Wind energy planning in England, Wales and Denmark: Factors influencing project success" Energy Policy 35: 2648-2660.

Montjoy, R. O'Toole, L. (1979) “Toward a Theory of Policy Implementation: An Organizational Perspective" Public Administration Review 39(5): 465-476.

Nadai, A. (2007) "“Planning", "siting" and the local acceptance of wind power: Some lessons from the French case" Energy Policy 35: 2715-2726.

Nadai, A. Labussiere, O. (2009) "Wind power planning in France (Aveyron), from state regulation to local planning" Land Use Policy 26: 744-754.

Ostrom, E. (1990) Governing the Commons: The Evolution of Institutions for Collective Action. Cambridge: Cambridge University Press.

Ostrom, E. (2001) "Vulnerability and Polycentric Governance Systems" IHDP Newsletter 3/2001.

O’Toole, L. (2000) "Research on Policy Implementation: Assessment and Prospects" 
Journal of Public Administration Research and Theory 10(2): 263-288.

Piteå Kommun. Översiktsplan Piteå Kommun: Fördjupning för Landsbygden -

Utlåtande: Yttranden som Inkommit Efter Utställningen - Antagandehandling 2007-

10-21.

PiteåTidningen (PT 1). "En jättechans till många nya jobb" 2007-07-05.

PiteåTidningen (PT 2). "Vindkraft för miljarder i Markbygden" 2006-10-17.

PiteåTidningen (PT 3). "Vi tackar ja till vindkraft" 2007-02-05.

PiteåTidningen (PT 4). "Vindkraft - ett sätt att bevara atmosfären" 2007-11-22.

PiteåTidningen (PT 5). "Nya vindar ger energi" 2006-12-16.

PiteåTidningen (PT 6). "Nej till vindkraft i Långträsk" 2007-03-22.

PiteåTidningen (PT 7). "Byråkrati kan stoppa industriprojekt" 2007-12-21.

PiteåTidningen (PT 8). "Hövdingen vill få oss att tänka i nya banor" 2007-06-29.

PiteåTidningen (PT 9). "När dim man lättade skingra des Sjölunds oro" 2007-02-26.

Pressman, J. Wildavsky, A. (1973) Implementation. Berkeley: University of California Press.

Sabatier, P. Brasher, A. (1993). "From Vague Consensus to Clearly-Differentiated

Coalitions: Environmental Policy at Lake Tahoe, 1964-85" in Policy Change and

Learning eds. Sabatier, P. Jenkins-Smith, H. Boulder, Co: Westview Press, pp. 149176.

Sabatier, P. A. Jenkins-Smith, H.C. (eds.) (1993) Policy Change and Learning: An Advocacy Coalition Approach. Boulder, CO: Westview Press.

Sabatier, P., Jenkins-Smith, H. (2007) "The Advocacy Coalition Framework: An

Assessment." In P. A. Sabatier (ed.) Theories of the Policy Process. Boulder, CO:

Westview Press, pp. 117-166.

Saetren, H (2005) "Facts and Myths about Research on Public Policy Implementation:

Out-of-Fashion, Allegedly Dead, But Still Very Much Alive and Relevant" The Policy Studies Journal 33(4): 559-582.

Skelcher, C. (2005). "Jurisdictional Integrity, Polycentrism, and the Design of

Democratic Governance" Governance: An International Journal of Policy, Administration, and Institutions 18(1): 89-110.

Smith, T. (1973) “The Policy Process Implementation" Policy Sciences 4: 197-209.

Sotirov, M. Memmler, M. (2012) "The Advocacy Coalition Framework in natural

resource policy studies - Recent experiences and further prospects" Forest Policy and Economics 16: 51-64.

Swedish Energy Agency (2016). "Riksintressen för vindbruk" Accessed at:

http://www.energimyndigheten.se/fornybart/riksintressen-for-

energiandamal/riksintressen-for-vindbruk/ on March 5, 2016.

Söderholm, P. Ek, K. Pettersson, M. (2007) "Wind power development in Sweden:

Global policies and local obstacles." Renewable and Sustainable Energy Reviews 11: $365-400$.

Szarka, J. (2004) "Wind Power, Discourse Coalitions and Climate Change: Breaking the Stalemate?" European Environment 14: 317-330.

Szarka, J. (2006) "Wind power, policy learning and paradigm change" Energy Policy 34: 3041-3048. 
Szarka, J. (2007) "Why is There No Wind Rush in France?” European Environment 17: 321-333.

Szarka, J. (2010) "Bringing interests back in: using coalition theories to explain European wind power policies" Journal of European Public Policy 17(6): 836-853.

Thelen, K. Steinmo, S. (1992). "Historical institutionalism in comparative politics" in Steinmo, Thelen \& Longstreth (1992) Structuring Politics - Historical Institutionalism in Comparative Analysis. Cambridge: Cambridge University Press.

Todt, O. Gonzalez, M.I. Estevez, B. (2011) "Conflict in the Sea of Trafalgar: offshore wind energy and its context" Wind Energy 14:699-706.

Toke, D. Breukers, S. Wolsink, M. (2008) "Wind power deployment outcomes: how can we account for the differences?" Renewable and Sustainable Energy Reviews 12(4): 1129-1147.

Warren, C. Lumsden, C. O'Dowd, S. Birnie, R. (2005) “'Green On Green’: Public perceptions of wind power in Scotland and Ireland" Journal of Environmental Planning and Management 48(6): 853-875.

Weible, C.M. Sabatier, P.A., Jenkins-Smith, H.C. Nohrstedt, D. Henry, A.D. deLeon, P. (2011) "A Quarter Century of the Advocacy Coalition Framework: An Introduction to the Special Issue" The Policy Studies Journal 39(3): 349-360.

Weible, C. Sabatier, P. McQueen, K. (2009) “Themes and Variations: Taking Stock of the Advocacy Coalition Framework" The Policy Studies Journal 37(1): 121-140.

Wiener, J. Koontz, T. (2010) "Shifting Wind: Explaining Variation in State Policies to Promote Small-Scale Wind Energy.” Policy Studies Journal 38(4): 629-651.

Wildavsky, A. (2007) Speaking Truth to Power. The Art and Craft of Policy Analysis.

New Brunswick, N.J: Transaction Publishers.

Young, O. (2002). "Institutional Interplay: The Environmental Consequences of Cross Scale Interactions" In Ostrom, E. et al. (Eds.), The Drama of the Commons. Washington, D.C.: National Academy Press (pp. 259-291). 